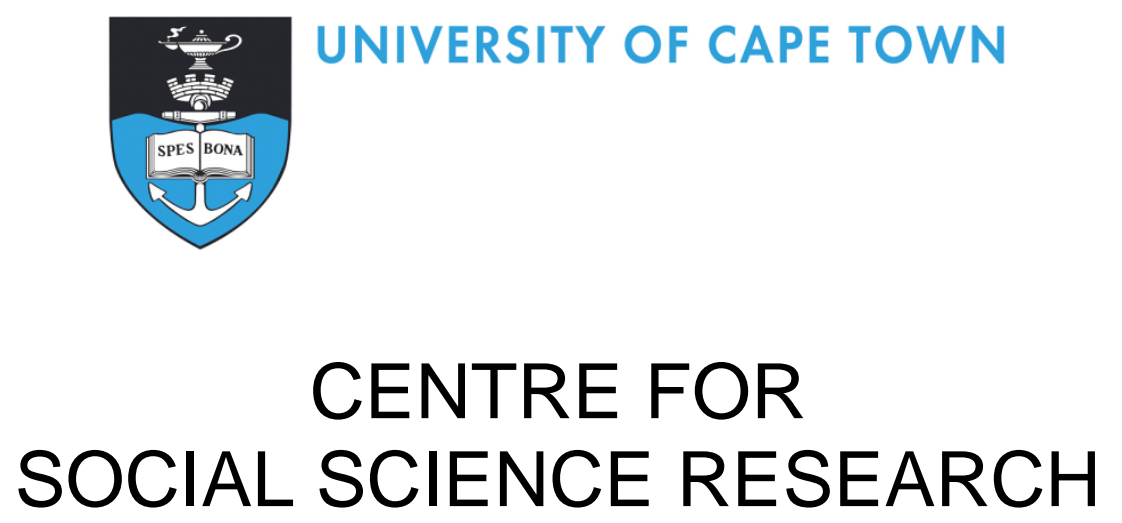

\title{
Forms of Femininity at the End of a Customary Marriage
}

Elena Moore

CSSR Working Paper No. 348

December 2014

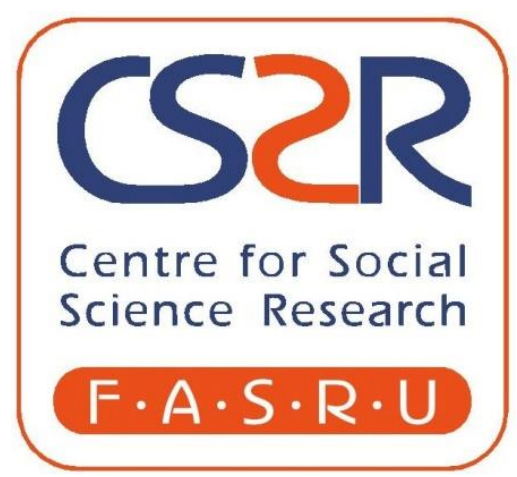



Published by the Centre for Social Science Research
University of Cape Town
2014

http://www.cssr.uct.ac.za

This Working Paper can be downloaded from:

http://cssr.uct.ac.za/pub/wp/348/

ISBN: 978-1-77011-335-0

(C) Centre for Social Science Research, UCT, 2014

\begin{abstract}
About the author:
Elena Moore is a Senior Lecturer in Sociology and a Senior Researcher at the Centre for Social Science Research, at UCT

Acknowledgements:

This work is based upon research supported by the South African Research Chairs Initiative of the Department of Science and Technology and the National Research Foundation. The author would like to thank the NRF Chair, Prof. Chuma Himonga, in facilitating and supporting this collaboration. The research described in this article is drawn from a larger research project on the Operation of the Reformed Customary Law in Practice: The Recognition of Customary Marriages Act and Rules of Intestate Succession Introduced by the Constitutional Court in Bhe v Magistrate Khayelitsha.

The article could not possibly have been written without the extensive support, comments and constructive discussions with the NRF Chair in Customary Law, Prof. Chuma Himonga.
\end{abstract}




\section{Forms of Femininity at the End of a Customary Marriage}

\section{Abstract}

This paper explores women's daily practice of resistance built into the racialised and gendered social structure of customary marriages in South Africa. I argue that women resist, accommodate, adapt and contest power and authority in the decision to leave the marriage, in negotiating the exit from the marriage and in their approach to the financial consequences of the separation. By using the myriad of daily practices as evidence for resistance, the study identifies three forms of femininities which emerge from the data: emphasised femininity characterises women's compliance with women's subordination, ambivalent femininity describes a complex combination of compliance and resistant activities in women practices and alternative femininities typifies the rejection and resistance with women's subordination. The paper discusses how these different forms of femininity emerge in their specific cultural, class and temporal context. The findings reveal that the resistance practices are accompanied by more general ideological awareness of how gender and class shape the lives of these women at this time of transition.

\section{Introduction}

'In the first days of your marriage the aunties, uncles and all the family, they will come and tell you that "lady, you must know that this man is your head, you are the neck. Whatever he is telling you, or whatever he is saying, that's the word, he's the head, you don't have to challenge him." Where I come from, if you challenge whatever a man has said you will be called by names.'

A member of a discussion group held in a rural area in the South African province, Limpopo, explained how power in the customary marital relationship is managed from inside as well as outside the marital relationship. This quote has a much broader ideological reach, and demonstrates the structuring of unequal social relations between genders and generations in the arena of marriage. Scholars have demonstrated that in the context of racialised oppression and colonial rule, and in a context where income poverty remains a gendered and racial phenomenon, marriage enables many women to improve 
their access to resources and social networks, while often compelling them to comply with gender-conforming practices (Kandiyoti, 1988; Rashid, 1995; Mnisi Weeks, 2011). The evidence in South Africa demonstrates that the ending of the marriage, through separation, divorce or the death of a husband, exposes wives to unequal power relations between their co-wives (Pienaar, 2003; Mbatha et al., 2007), their former husbands (Griffiths, 1997; Budlender et al., 2011), and their husbands' families (Griffiths, 1997; Burman, 2008; Classens and Ngubane, 2008; Budlender et al., 2011). The dissolution of a customary marriage offers an opportunity to examine the complex hierarchy of power and authority arrangements between men, women and related others and allows us, in this paper, to pay more attention to women's 'forms of consciousness and struggle that emerge in times of rapid social change' (Kandiyoti, 1988: 284).

In this paper, I will present how women resist, accommodate, adapt and contest power and authority at the end of a customary marriage. A brief outline of the context of customary marriage and customary law in South Africa will be provided before presenting the theoretical background and the demographic data, in which the findings are located. Next, I will describe the research methods adopted for the study, and then present the three forms of femininity identified in this study. The final section will outline how women are fighting new areas of struggle and renegotiating relations between genders and generations.

\section{Customary law and marriage in South Africa}

For many African groups marriage can be considered a process which may take place over many years and involves relations between families (Griffiths, 1997: 53). Customary marriages were legally recognised more fully with the introduction of the Recognition of Customary Marriages Act 1998 (hereafter referred to as RCMA), as previously they were only partially recognised according to South African law. The Act defines a customary marriage "as a marriage in accordance with customary law" and customary law is defined in the Act as: "the customs and usages traditionally observed among the indigenous African peoples of South Africa and which form part of the culture of those peoples." Just over a quarter of all Black South Africans are married and $42 \%$ of those who marry opt for a customary marriage as opposed to a civil or religious marriage. ${ }^{1}$ Customary marriages can be monogamous or polygamous. A very

\footnotetext{
${ }^{1}$ These figures are based on the 2007 South African Community Survey. The Community Survey is a large-scale household survey conducted by Statistics South Africa to bridge the gap between censuses. The survey differentiated marital status by marriage type and allowed us to ascertain the number of people who are part of a customary marriage.
} 
small percentage of black South Africans ( 0.1 per cent) identified themselves as being part of a polygamous marriage.

Nowadays, all customary marriages must be dissolved by the court (defined by the RCMA as the High Court or Regional Court). The chiefs and headmen's courts established under the Black Administration $\mathrm{Act}^{2}$ (hereafter referred to as BAA) no longer have jurisdiction to dissolve marriages after the introduction of the RCMA. Approximately 2 per cent of the black South African population over the age of 14 considered themselves separated or divorced. ${ }^{3}$ Despite research evidence of ongoing marital dissolution over the last century (Burman, 1987; Ramphele, 1993; Posel, 1995; Budlender et al., 2011), the divorce rate amongst Black South Africans is very low.

During colonialism and apartheid, customary marriage laws were changed and 'invented' to exaggerate the patriarchal norms within customary marriages (Chanock, 1991; Nhlapo, 1991). African feminist scholars (Amadiume, 1987; Oyewùmí, 1997) have described how colonial rule eroded the socio-political and economic power of women in different parts of the continent. Scholars have outlined that in both southern Africa (Chanock, 1991; Schmidt, 1991) and South Africa (Walker, 1990; Posel, 1995) African chiefs and elder men were anxious about the control of 'unruly' African women. With the threat of industrialisation and urbanisation, the patriarchal alliance of African men and the state used "customary law" as a vehicle to refashion rural tradition and bring African women under control (McClendon, 1995: 527).

The racialised and gendered laws at this time acted as an oppressive system of domination. The exclusion of customary unions from the protection that civil marriages were afforded since the late 1920s was wrong but the exclusion and subordination of women from both was remarkable. Under the BAA, women were denied the right to acquire and own property in their own right. The BAA accorded customary union husbands absolute ownership of household property, which included the personal property and earnings of their wives. Moreover, the BAA regarded women as perpetual minors under the guardianship of either their male relatives or husbands. Access to courts was limited as women could not litigate without consent of or assistance by their legal guardians. This legal subordination continued to take place at a time when increased urbanisation (in the 1970s) increased pressure on African women to find paid work and most research evidence points to women's increasing economic independence.

\footnotetext{
2 The Black Administration Act was introduced by the colonial authorities in 1927 and remained in operation during the Apartheid period. For more details see Deveaux (2003).

${ }^{3}$ The official number of divorced or separated black South Africans obtained from the 2011 Census indicated that 525,792 black South Africans were divorced or separated. This number includes divorces from both civil and customary marriages.
} 
Despite having few legal rights, the research evidence outlines that women carried most responsibility for household maintenance (Walker, 1990).

With the end of apartheid and the arrival of democracy, the enactment of the RCMA ensured the recognition of customary marriages for black South Africans. ${ }^{4}$ The new laws not only improved womens' access to economic resources from a marriage, but they also improved womens' access to justice by having matters dealt with at the state court level only. The reformed laws theoretically provide women with rights to equality, but research evidence suggested that there continues to be structural and cultural barriers in African families and communities which make accessing these laws very difficult (Mamashela, 2004; Mbatha et al., 2007). This paper will reveal the challenges women experience while negotiating with family members their way out of a customary marriage.

\section{Resistance, compliance and levels of constraints: Power struggles in customary marriage}

Many feminist researchers use gender as the model for explaining women's subordination and oppression. However scholars have questioned the power of gender to explain African societies (Amadiume, 1987; Oyewùmí, 1997; Arnfred, 2007). Amadiume (1987) argued that the idea of male dominance and female subordination does not fully capture the dynamics of power as hierarchy depends on social relations and positions. One relation that must be taken into account is seniority (1987). Empirical findings on customary marriages from southern Africa partially support this argument as the evidence demonstrates that while gender discrimination is a pressing problem in domestic disputes, equally worrying for resolving disputes was ways of surviving and managing social relationships, particularly relationships women have with other women, including co-wives (Griffiths, 1997; Mnisi Weeks, 2012).

Another social relation more significant than gender difference in the African context, according to Oyewùmí (2004: 4), is whether a person is inside or outside a certain family or lineage. This often means that a wife, who marries

4 In particular, the RCMA accorded customary marriage wives legal entitlement to maintenance and half of the matrimonial property (unless an anti-nuptial contract is concluded). In addition it ensured women greater access to justice by granting women full legal capacity to litigate and access state courts and tasking the state judicial system with the responsibility of ensuring that equitable outcomes in matters relating to the exit out of customary marriages are achieved. 
into a family, assumes a subordinated position, as is the case in most patrilineal societies. Oyewùmí (2004) argued that this position is less about gender and is fixated on the 'outsider' status. In arguing this case, she points to the fact that in matrilineal societies the in-married person will be a man, whereas in patrilineal societies the in-married stranger will be a woman. The subordination of a wife rests in her position vis-à-vis the lineage in question and the seniority in question and not in the biological sex of this person. Oyewùmí (2004) criticised feminist theorising which has it's the exclusive focus on the nuclear family. Theorising from the limited space of the nuclear family overlooked the place of other adults, whether as co-wives, or blood related others. Such actors have been shown in South African research to yield significant power as deserted wives and widows have experienced patriarchal authority from different members of the deceased male's relatives (Burman, 2008; Classens and Ngubane, 2008; Budlender et al., 2011; Mnisi Weeks, 2011).

While acknowledging the problems with adopting categories uncritically and distorting local structuring dynamics and modes of understanding, Bakare-Yusuf (2004) argued that Oyewùmí is guilty of the same practice by focussing exclusively on seniority or lineage which may or may not carry the same value when translated into other cultural contexts (2004: 66). Bakare-Yusuf (2004), in line with other feminist scholars (Crenshaw, 1989; Hill Collins, 1990; Ferree, 2010), urges researchers to take the interwoven nature of power dynamics seriously by examining the specific value of each variable of power operating in a given situation. So what do we know about how dominant groups or classes successfully retain power in intimate relationships in South Africa?

Most recently, Jewkes and Morrell wrote that 'in a highly gender-inequitable country like South Africa, hegemonic masculinity mobilises and legitimates the subordination and control of women by men' (2010: 3). Scholars argue that the dominant ideal of a submissive, respectful African woman to males, elders and specific family relations remains (Ruddick, 2001; Jewkes and Morrell, 2010; Mbatha, 2011). It is argued that excusing male behaviour, such as violence or infidelity, is an integral part of the dominant femininity for African women (Jewkes and Morrell, 2010). The authors contend that such compliance is usually socially rewarded which is essential for women's security (2010). They maintain that other forms of femininity are punished by the practice of marginalisation and stigma and are therefore absent (2010). In presenting this argument, based on spurious grounds, the authors cite the lack of divorce amongst African women as a sign of dominant forms of emphasised femininities. While there is a low rate of divorce amongst black South Africans, this phenomena has other possible explanations (Hosegood et al., 2009). The low rate of divorce should not be viewed solely as women's failure to leave marriages or their compliance with subordinated practices within marriages. 
However, this forces us to examine the strategies that black women use to express their specific situatedness in respect of unjust hierarchal social relationality.

Local, small scale qualitative research studies have demonstrated unique ways in which women resist unequal power relations in intimate relationships (Magwaza, 2001; Mathonsi and Gumede, 2006). Mathonsi and Gumede (2006) demonstrated how Zulu women, through performance and song (izigiyo) protest against abusive social systems which they experience at the hands of family and community members. These songs of protest give women a voice albeit within a limited (indoors and usually amongst a community of women) public sphere. In a separate study, Magwa (2001) detailed how rural and illiterate Zulu (CamperNdwedwe) women are not passive about their situations, but employ dress in ways that not only signify their compliance with traditionally ascribed status, but also their displeasure, as a form of non-verbal protest. Both authors highlight the need to examine the private and individual forms of protest, as a way of encouraging other women to talk about their positions in male-dominated relationships.

So how can we explain why women may excuse sexism and subordination in intimate relationships? Why do women who demonstrate gender awareness, tolerate sexism or inequality in intimate relationships? The theoretical construct of patriarchal bargains, developed by Kandiyoti (1988) may be useful in this case. Patriarchal bargains, as argued by Kandiyoti (1988: 283) are said to influence both 'the potential for and specific forms of women's active or passive resistance in the face of oppression.' Kandiyoti presented two very different systems of male dominance and women's resistance in contrasting class, caste and ethnic contexts. She found that it was the insecurities of African kinship systems for women in subSaharan Africa which informed women's marital and marketplace strategies, which were characterised as active forms of resistance. She contrasts these experiences with women's accommodations to 'classic patriarchy', a system based on patrilineal, patrilocal relations of the extended household. Kandiyoti (1988: 283) argued that women's compliance may be forced when there are no other alternatives. In such cases, women's passive resistance takes the form of "protection in exchange for submissiveness and propriety." Another possible explanation provided by England (2010) suggests that women transgress gender boundaries purely as a way of seeking upward mobility rather than as a pursuit for its own sake. England (2010) stresses that women will react to gender structures in whatever way improves their livelihood and security and are less motivated to seek equal opportunities purely for the sake of undoing gender differentiation. These explanations require us to explore how gender relations operate in a broader context of disadvantage for Black South African women. 


\subsection{Socio-economic context of women in customary marriage}

Black South African females are more at risk of poverty than any other group in South Africa (Posel and Rogin, 2009). Below I compare the socio-economic position of men and women in civil and customary marriages for black and white South Africans. The position of white South Africans (male and female) has been included in the table to outline the ongoing racialised (and gendered) position of disadvantage for black women in customary marriages. As the figures in Table 1 demonstrate, there are noteworthy differences in terms of educational attainment, employment status and individual monthly income between black and white South Africans. However, comparing black Africans in customary marriages with black Africans in civil marriages, we see that black African men and women in customary marriages have a lower educational attainment, a lower level of employment and lower income compared to their counterparts in civil marriages.

What issues might emerge if issues of race and class generally, and understanding of being an African customary wife specifically, became central to feminist theorising about exiting a marriage? Ignoring racial and class differences creates specific problems. Firstly it overlooks the relative economic insecurity which exists for Black South African customary wives and secondly, it may overlook the dependency women in customary marriage have on their husbands and families, in their struggle for power. The continued pattern of economic and educational exploitation and disadvantage built into the racialised social structure shapes the context for Black South African women in customary marriages. 
Table 1: Educational Attainment, Employment Status, and Individual monthly income by race, sex and marriage type (Community Survey Data 2007, $n=1$, 047, 652)

\begin{tabular}{|c|c|c|c|c|c|c|}
\hline & \multicolumn{4}{|c|}{$\begin{array}{c}\text { BLACK }(\mathbf{n}=806,498) \\
(77 \%)\end{array}$} & \multirow{2}{*}{\multicolumn{2}{|c|}{$\begin{array}{c}\text { WHITE }(\mathbf{n}=\mathbf{1 0 1}, \mathbf{1 9 6}) \\
(\mathbf{9 . 7 \%}) \\
\text { Civil Marriage } \\
(n=34504) \\
(48 \%)\end{array}$}} \\
\hline & \multicolumn{2}{|c|}{$\begin{array}{c}\text { Customary Marriage } \\
\left(n=58319^{*}\right) \\
7 \%\end{array}$} & \multicolumn{2}{|c|}{$\begin{array}{c}\text { Civil Marriage } \\
\left(\begin{array}{c}n=79547) \\
10 \%\end{array}\right.\end{array}$} & & \\
\hline & $\begin{array}{c}\text { Women } \\
\mathrm{n}=\mathbf{3 0} 831 \\
\mathbf{5 3 \%}\end{array}$ & $\begin{array}{c}\text { Men } \\
\mathrm{n}=27488 \\
47 \%\end{array}$ & $\begin{array}{c}\text { Women } \\
\mathrm{n}=41 \mathrm{186} \\
52 \%\end{array}$ & $\begin{array}{c}\text { Men } \\
\mathrm{n}=38361 \\
\mathbf{4 8 \%}\end{array}$ & $\begin{array}{c}\text { Women } \\
\mathrm{n}=17226 \\
50 \%\end{array}$ & $\begin{array}{c}\text { Men } \\
\mathrm{n}=\mathbf{1 7 2 7 8} \\
\mathbf{5 0 \%}\end{array}$ \\
\hline \multicolumn{7}{|l|}{$\begin{array}{l}\text { Educational } \\
\text { Attainment (\%) }\end{array}$} \\
\hline No schooling & 25 & 22 & 13 & 13 & 0.3 & 0.2 \\
\hline Primary schooling & 33 & 37 & 29 & 31 & 2 & 2 \\
\hline $\begin{array}{l}\text { Some Secondary } \\
\text { Schooling }\end{array}$ & 31 & 27 & 33 & 30 & 24 & 23 \\
\hline Matric & 8 & 9 & 12 & 12 & 36 & 33 \\
\hline Post-Matric & 4 & 5 & 14 & 13 & 38 & 42 \\
\hline \multicolumn{7}{|l|}{ Employment Status } \\
\hline Employed & 27 & 56 & 38 & 63 & 55 & 72 \\
\hline Unemployed $* *$ & 21 & 13 & 19 & 10 & 3.1 & 1 \\
\hline $\begin{array}{l}\text { Not economically } \\
\text { active }\end{array}$ & 53 & 31 & 44 & 28 & 42 & 26 \\
\hline \multicolumn{7}{|l|}{$\begin{array}{l}\text { Individual (monthly) } \\
\text { Income*** }\end{array}$} \\
\hline No income & 52 & 24 & 43 & 18 & 31 & 6 \\
\hline $\mathrm{R} 1-\mathrm{R} 400(\$ 37)$ & 7 & 5 & 5 & 3 & 1 & 0.4 \\
\hline R401-R800 (\$75) & 10 & 10.5 & 8.6 & 7.2 & 2.1 & 2 \\
\hline R801 - R1 $600(\$ 150)$ & 22 & 30 & 21 & 25 & 6 & 5 \\
\hline R1 601 - R3 200 & 3 & 15 & 6 & 16 & 7.4 & 5 \\
\hline R3 201- R6 400 & 2 & 8 & 6 & 13 & 14 & 12 \\
\hline R6 401- R12 800 & 1 & 3 & 5 & 8 & 15 & 21 \\
\hline R12 801-R25 600 & 0.3 & 1 & 1 & 3 & 7 & 18 \\
\hline R25601-R51 200 & 0.1 & 0.3 & 0.3 & 1 & 3 & 10 \\
\hline R51201 - or more & 0 & 0.1 & 0.1 & 0.5 & 2 & 5 \\
\hline Response not given & 3 & 4 & 5 & 6 & 13 & 16 \\
\hline
\end{tabular}

** The derived employment status variable was used and is based on the official unemployment definition.

*** This question was asked to determine the income category that best describes the gross monthly or annual income before deductions. It includes all sources of income (including social grants).

\section{Methods}

The research described in this article is drawn from a larger research project on the Operation of the Reformed Customary Law in Practice: The Recognition of 
Customary Marriages Act and Rules of Intestate Succession Introduced by the Constitutional Court in Bhe v Magistrate Khayelitsha. Interview data from over 80 participants was collected between 2012 and 2013 in six provinces across South Africa. This article is based on semi-structured interviews with 19 women who self-identified as separated or divorced. ${ }^{5}$

All interviews were conducted in the homes of the participants and in the first language of the participant, which included Xhosa, Zulu, Sepedi and Tswana. The researchers collaborated with a non-profit organisation called the National Movement of Rural Women. The organisation manages projects in four of the sampled provinces, including Limpopo, North West, Mpumalanga and KwaZulu-Natal. Participants in these areas were recruited to attend an information session regarding the 'new laws.' Over 200 people attended the information sessions. Before the session took place, individuals were asked to sign a register which we used to create a sampling frame and obtain some of the necessary sampling criteria from the participants.

In the Eastern Cape and Gauteng - the provinces where the organisation is not present - we adopted snowballing methods of sampling. The researchers identified people in the community who met the sampling criteria and we snowballed from the first set of participants. This method was particularly useful as the key selection criteria are characteristics that are not widely discussed by individuals. Table 2 below outlines the description of the sample on which this article is based. As can be seen from Table 2, the spread of provinces, languages and ages of divorcees was broad-ranging. Two thirds of the participants included in this paper lived in rural areas. Just under half of the divorcees were unemployed, while the majority of employed divorcees worked in low-skilled, low-paid jobs such as retail or factory work. There were two skilled employees in the divorce sample. The educational attainment is fairly low, with two thirds of the sample not completing secondary schooling.

\footnotetext{
${ }^{5}$ Divorce and marriage dissolution can be formal or informal. Some people who consider themselves divorced are not considered divorced from the perspective of the State but may be considered divorced by members of their community. Therefore in recruiting a sample of 'divorcees', we included any individual who self-identified as a divorcee.
} 
Table 2. Description of the Sample

\begin{tabular}{|c|c|c|c|c|c|c|c|c|c|}
\hline & Respondent & Province & Rural & Age & $\begin{array}{c}\text { Educational } \\
\text { attainment }\end{array}$ & Employed & Job type & $\begin{array}{c}\text { Length of marriage } \\
\text { (years) }\end{array}$ & $\begin{array}{c}\text { No. of marital } \\
\text { children }\end{array}$ \\
\hline & Thulile* & North West & Rural & 42 & Grade 8 & No & N.A. & 17 & 2 \\
\hline \multirow{8}{*}{ 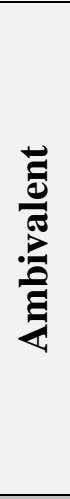 } & Katlego & Limpopo & Rural & 43 & No schooling & Yes & Fruit picker & 2 & 4 \\
\hline & Thobile & Limpopo & Rural & 34 & Grade 8 & Yes & Informal Trader & 16 & 3 \\
\hline & Matete & North West & Rural & 27 & Grade 8 & Yes & Cashier & 3 & 1 \\
\hline & Dumile & KwaZulu-Natal & Rural & 43 & Grade 8 & No & NA & 2 & 0 \\
\hline & Yvonne & Gauteng & Urban & 40 & Post-matric & No & N.A. & 3 & 0 \\
\hline & Mpumi & Gauteng & Urban & 37 & Grade 11 & Yes & Secretary & 10 & 1 \\
\hline & Amanda & Gauteng & Urban & 38 & $\begin{array}{l}\text { Post-matric } \\
\text { diploma }\end{array}$ & Yes & Secretary & 6 & 1 \\
\hline & Kenelieliwe & North West & Rural & 61 & Grade 10 & No & $\mathrm{NA}$ & 25 & 3 \\
\hline \multirow{10}{*}{ : } & Vuyiswa & Limpopo & Rural & 42 & $\begin{array}{l}\text { Post-matric } \\
\text { diploma }\end{array}$ & Yes & Traffic officer & 14 & 2 \\
\hline & Ms Dube & Eastern Cape & Urban & 41 & Grade 6 & Yes & Factory worker & 19 & 2 \\
\hline & Thembi & Gauteng & Urban & 53 & Grade 11 & No & N.A. & 13 & 0 \\
\hline & Kagiso & Limpopo & Rural & 30 & Matric & Yes & Fruit picker & 2 & 3 \\
\hline & Rosalie & Limpopo & Rural & 37 & Matric & No & N.A & 9 & 0 \\
\hline & Zukiswa & KwaZulu-Natal & Rural & 52 & Grade 5 & No & N.A. & 35 & 1 \\
\hline & Marthe & Limpopo & Rural & 65 & Grade 6 & Yes & Project leader & 42 & 2 \\
\hline & Violet & KwaZulu-Natal & Rural & 42 & Grade 11 & $\mathrm{No}$ & N.A. & 3 & 2 \\
\hline & Cynthia & Eastern Cape & Rural & 40 & Grade 11 & No & N.A. & 3 & 2 \\
\hline & Siphwo & Eastern Cape & Urban & 36 & $\begin{array}{l}\text { Post-matric } \\
\text { diploma }\end{array}$ & Yes & Teacher & 8 & 2 \\
\hline
\end{tabular}

*There was only one divorcee who complied with the gender hierarchy following the end of her customary marriage. 


\subsection{Data Collection}

Approval for the research was sought from and granted by the Research Ethics Committee at the Law Faculty, University of Cape Town. The research team obtained informed consent from the participants at multiple stages of the research. All major identifiers (names of individuals, specific locations) were removed from data. In the findings that follow, pseudonyms are used. The interview guide used during interviews contained four sections, seeking to cover aspects of the personal background of the participant, the conclusion of the marriage, the termination of the marriage, and the post-separation arrangements. The sections relevant to this article focus on the termination of the marriage and the post-separation arrangements. We asked open-ended, non-directive questions about these processes (e.g. "Can you tell me about the troubles in your marriage?", "Who did you turn to for support?"). We prompted participants only to a minimal degree to follow up an interesting narrated experience (e.g. "Could you tell me in more detail how you experienced the consultations at his home?").

\subsection{Data Analysis}

The method of data analysis followed the 'conceptual scaffoldings' approach outlined by Spencer et al. (2003: 213). This method involves three overlapping stages. The first stage involved sorting and reducing the data by generating a set of codes. For example, I used 'family meeting' as the initial broad structural code; I coded all data relating to the 'family meeting' and I sorted the data into different structural codes: 1) parties present, 2) method of including families, 3) reconciliation or fault based, and 4) hearing or briefing (outcome decided in advance). In the second stage of analysis the nuances and tensions within each category were analysed and incorporated into the analysis. For example, in some cases, the meeting was a hearing, where all parties had an opportunity to express their views, while in other cases the meeting was a briefing session, where a decision was already made. The outcome of the meeting was either predetermined or unplanned. In the third stage a typological classification was established to capture womens' perspectives and responses to the family meeting. Two dimensions were used in the designation of categories engagement with the family meeting and the intention of the outcome of the family meeting. The three categories established were 1) emphasised femininities, ${ }^{6}$ 2) ambivalent femininities, and 3) alternative femininities.

\footnotetext{
${ }^{6}$ Connell (1987) used the term 'emphasized femininity' to characterise women's compliance with women's subordination and an approach which accommodates the interests and desires of men.
} 
Emphasised femininities included women who wanted to engage in the process and sought a resolution to the dispute which would result in reconciliation. Ambivalent femininities include women who engaged with the process and did not have any intended outcome of the meeting. Alternative femininities included women who either engaged or did not engage with the process but had predetermined the outcome of the meeting.

\section{Findings}

The findings will be presented according to the ways in which women comply or resist power and authority when negotiating 1) with their husbands (deciding to end the marriage), 2) with their husbands' families (during family meetings), and 3) the financial consequence of the separation. The women fell into three main categories: emphasised femininities, ambivalent femininities and alternative femininities. Emphasised femininity is characterised by women's compliance with women's subordination; ambivalent femininity describes a complex combination of compliance and resistant activities in women practices and alternative femininities typifies the rejection and resistance with women's subordination.

\subsection{Emphasised Femininity}

There was only one divorcee who did not identify gendered processes as sources of oppression. Thulile, a 42 year old divorcee, had been married for 17 years and had two children. She discovered her husband was having a long-standing affair with a woman who occupied the marital couple's second home in the city. When she confronted her husband, he ended the marriage by bringing her back to her natal $\mathrm{kin}^{7}$ :

'He gave me to my mother and said to her "I brought her back for you to talk to her and advise her." So my mother asked, "What do I do after I have done that?" And he said he would come back. The old woman has been waiting since then. No, I have never said I am going to get him.'

Thulile's family were unable to obtain a response from the husband's family and were left powerless and frustrated as Thulile explained: 'he [her father] got very

\footnotetext{
7 This act is a manifestation of his intent to end the marriage, a conventional customary procedure where the man escorts his wife back to her family (South African Law Commission, 1998: 129).
} 
angry and I told him to wait and then he passed away. I told my mother to not let it bother her, we should wait on them.' Her actions and thoughts of passive resistance are limited and defined within a patriarchal set of beliefs and practices. The loss of her position entails a loss of economic and social status so rather than step out of line and question norms, respectability and authority, she accepted them and hopes the husband will return for her.

The former marital couple had significant assets as they possessed two properties. Thulile did not believe that she had contributed to the marital property:

'Yes, I just came with my clothes. He is the one who was packing for me. I wasn't working. When I leave, I cannot say I am taking all the things. I need to understand that I was not working. He was the one who was working so when he says we are not sharing them. I need to accept that he doesn't want me and he doesn't want me to take anything.'

Mamashela argued that movable assets are bought with the husband's money and therefore 'belong' to him (2004: 632). Thulile did not question her husband's actions as she did not believe she had any role to play in the decision making process concerning the ending of the marriage, the resolution of the dispute or the financial consequences of the separation. It has been argued that such a stance can be attributed to differentiation between husbands and wives arising from prescribed gender roles (Samuel, 1999) and may shape the more unconscious aspects of their gendered subjectivity (Kandiyoti, 1987). Questioning their status is seen as questioning customary practices in principle and figures in authority, which places a woman in a very precarious social position from which she could lose her respectability (Kandiyoti, 1988; Samuel, 1999: 23). The observance of restrictive practices is such a crucial element in the reproduction of personal and family status that women, like Thulile, will resist breaking the rules, even if observing them produces economic hardship. Thulile has been waiting since 2003 and lives with her two children, her mother and her brother. She got married in 1994 whilst in Grade 8 and left school shortly afterwards. She did not work during the marriage and has not worked since the couple separated.

\subsection{Ambivalent Femininity}

There were eight divorcees who demonstrated practices of resistance and compliance following the end of their customary marriage. Ambivalent femininities acknowledge the coexistence and combination of compliance and 
resistant activities in women practices. Although women resisted pressures to remain in an unequal marriage, one in which men were adulterous or abusive, women were also fearful of spoiling social relationships with the wider family and did not contest the financial consequences of a separation.

The women in this group showed their resistance by publically displaying their dissatisfaction with the marriage in a number of ways. While some women left the family home for a period (signs of resistance) only to return again (signs of compliance), others consulted traditional leaders or turned to elders as a way of publicising their grievance and signalling their discontent with the marital relationship. Katlego, a 43 year old divorcee left the family home for a period of time and upon her return she called a family meeting. Katlego, who was the second wife in a polygamous marriage, explained how she could no longer tolerate a marriage where the first wife assumed control and authority over her position: 'The problem was his first wife; we used to argue a lot.' The higher status as the first wife, as depicted in the research evidence (Mbatha et al., 2007) enabled the first wife to exercise control and mediate between the husband and Katlego, this became unbearable for Katlego and she left the marriage.

Thobile, a 34 year old mother with three children had also left the marital home for a period to signal her discontent. While her return to the marital home signalled her willingness to resolve their dispute, upon her return her husband and his family responded adversely:

'He loved women he was bringing them home. [In your house?] Yes, in my house. Yes I sat down with him and told him that something was not right. I first went home, then second month I came back to my house I then told him that I was back and he said I don't want you to come inside my room. At the family meeting they told me that he doesn't want me because he's going to marry another wife.'

The family meeting did not act as a forum to resolve the dispute and Thobile was ushered out of the marriage by his family. In many cases, paternal families overlooked the misbehaviour of their son and pressurised the woman to remain in an abusive marriage. Matete, a 27 year old cashier, who had one marital child and was married for 5 years, explained how she had to justify leaving the marriage to both her husband's family and others in the community:

'He liked chasing other women, that's why I left him. His family said I should wait for the elders to talk first and I didn't want to listen. This woman loved her son too much. I would try to explain to her that her son was not spending nights at home, this is what he does.' 
Kandiyoti (1988: 279) explained that "older women may have a vested interest in the suppression of romantic love between youngsters to keep the conjugal bond secondary and to claim sons' primary allegiance." It is for this reason that 'insider-outsider' family relations can be a more significant determinant for hierarchy, as experienced by Matete. However the extent, to which Matete publically and privately justified her departure, highlighted the social pressure she experienced to justify her departure: 'I went (to the Chief) on my own. I went to them to let them know what their son is like. I don't want them to speculate as to why I left.' Informing the traditional leader exemplifies compliance with processes by which a marriage should be dissolved before the enactment of the RCMA. At the family meetings, many of the wives in this group opposed the wishes of the paternal families. In doing so, they resisted pressure to remain in the marriage and stepped 'out of line' and left the marriage.

Dumile, the second wife in a polygamous marriage, who left the marriage three years after getting married, returned to her family after she confronted her husband about her dissatisfaction with the marriage:

'I was hurt. When they (co-wives) come here at home they can't even greet me. But I stayed, I was thinking about the people in the community, they would say I'm playing with an old man now I got what I wanted I'm leaving him. I told his family many times but I never got any help. I realised that I was just there as his helper.'

Dumile complied with the arrangement 'as his helper' for three years and alluded to the fact that the arrangement involved an exchange of respect for the husband and co-wives in return for security. Dumile's husband was considered a wealthy man in the community. This decision occurred in an environment where the range of options to secure a livelihood was extremely restricted. She had left school in Grade 8 and had never been employed. She put a bit of pressure on her husband to change the situation as she hoped she could, with his help, become more self-sufficient:

'He doesn't want me to work. I said he must give me at least R2, 000 [\$180] maybe I would buy some chickens then sell them and he said he didn't want people coming here.'

Eventually she realised that she was not well protected in the marriage and she decided to leave. She is currently living in a household with twelve other family members and is responsible for caring for the children in the extended family: 
'I'm the eldest these kids here are my sisters who were before me two of them died one had eight kids the other one had three kids, some are still at school but I'm the eldest, I am responsible for them.'

The women in this group, like Dumile, demonstrated their resistance to remain in a subordinated position by leaving the marriage, even in situations which resulted in loss. For the eight women who left the marriage and marital home, they did not pursue any claim to the movable or immovable property. The eight women left the marriage with nothing but their clothes, as Matete explained:

'I left them (the property) with him. [Why?] There would have been problems. It was going to raise problems where his family says our child has worked hard now you are taking his things and going to your family.'

Matete, like others, was afraid of what others would say if she questioned customary practices and sought a more equitable share in the marital property. The social relations between the families would be spoiled if the women pursued a claim to marital property, something that was not part of the customary norm and they feared they would lose their respectability in the process, as Katlego explained 'I did not want people saying that I only married him for his assets.'

\subsection{Alternative Femininities}

Ten of the women in the sample engaged in ongoing resistance as they opted out of the marriage and fought for equality of income and opportunity. Similar to women in the previous group, the women in this group demonstrated resistance by displaying their discontent with the quality of the marital relationship. However, unlike the women in the last group, the women in this group were unwilling to tolerate unequal outcomes of the separation. Moreover, unlike the previous group of women, these women were less concerned about the risk of social ostracism in leaving the marriage. Essentially, they were not willing to tolerate oppressive marital relationships in exchange for security as they saw alternatives.

Women in this category were unhappy with their husband's marital behaviour and sought to confront their husbands and their husbands' families about the matter. Kagiso, who was married for 4 years and had two marital children, confronted her husband about his affair and eventually left her husband as she could no longer tolerate his infidelity. In doing so, Kagiso described the challenge she had to face during the family meeting: 
'Yes I told my mother-in-law that I wanted to leave, but she does not approve... but I told her I am still young and cannot continue to be in a marriage where my husband is cheating on me.'

By rejecting 'customary resolutions' for resolving marital disputes, Kagiso was able to draw attention to the unacceptability of such behaviour. Siphiwo, a 36 year old recently graduated teacher from the Eastern Cape, left the marriage after 8 years. After informing her family of her intentions, she informed her husband's family:

'I first consulted my own family and I told them that I wanted to tell my in-laws. I called a meeting and I told them that I had decided to rather go out and do something for myself.'

Siphiwo had experienced considerable hardship in the marriage as her husband was drinking heavily and was abusive. She obtained a protection order against the husband and she moved out of the marital home three years before she obtained a divorce. Zukiswa explained how she 'told her family and her husband's family: 'I told them it was over'. The form of expression of discontent is telling as the individual is no longer seeking a resolution but is determined to exit the marriage. The exit contributes to a larger cultural context in which changes in convention are occurring. The women's actions may not be socially legitimated as they do not always follow the 'correct' dispute resolution path - in many cases they are not seeking a resolution from the family, and they are merely informing the family of their decision.

Kagiso was working, albeit in low-paid farm work, and was able to support herself financially after leaving the marriage. Siphiwo too, despite facing considerable economic constraints leaving the marriage, still pursued it:

'When I moved out to rent my own space, the kids were not staying with me as I couldn't afford them. I was earning R500 (\$47) per month and hoping that one day I was going to be employed like now.'

This quote demonstrates the resource base and ability to earn wages and survive, whilst caring for children. It is within this constrained socio-economic context that Siphiwo and Kagiso choose to leave a marriage.

Violet experienced extensive conflict and violence as her husband tried to end the customary marriage. Central to her display of discontent were practices which resisted and challenged the normative expectations posed by the husband and his mother: 'He woke me up in the early hours of the morning ...he was telling me to take everything and go back home I told him that he won't do that 
here.' Violet was called to a family meeting but she refused to leave the marital home. Her former husband was looking to marry another woman who he had been residing with for the previous year. The ownership over the marital home and the custody of a 10 year old son were contested as Violet was not willing to concede. The terms of the separation was contested over 6 months and during this time the father failed to pay maintenance to the children who were residing with Violet. Violet rented out two rooms in the marital home as a way of generating income during this interim period. When her former husband found out about this, he returned to the house and beat her up. This physical beating was a form of coercion and control to which Violet's ex-husband relied upon in order to impose his will. Violence was the means to secure conformity. However, Violet did not give in but obtained a protection order following this outburst and put an end to the intimidation. At the time of the interview, a year after the separation, there were 14 months maintenance payments in arrears. The findings demonstrate how families (and former husbands as fathers) distort the material relations within which Violet is starting her new household. Violet managed to obtain a right to remain in the marital home and the custody of both her children. She continued to use the marital home as a way of obtaining an income.

The women in this group refuse to cooperate and accept the terms on which the couple separate. They seek redress; they employ personal strategies to enhance their economic stability post marriage. Such strategies include hiding furniture away as a way of avoiding the financial repercussions of the separation ('when I saw that our relationship was getting worse, I used to buy and store items at my family home'), resisted pressure to return bride price by threatening a claim for maintenance and a stake in other assets; or 'by doing their research', checking the terms of pension and insurance policies, or finding employment. In pursuing such strategies of ensuring economic survival, they often enlist the help of others in the public world adding to the public nature and display of their discontent. Kagiso fought to obtain maintenance for her children as she explained how she sought a garnishee order by visiting the former husband's employer: 'I went to his place of work to try and speak to him. I wanted him to sign papers that would enable him to start paying maintenance fees for his children.' While Kagiso lived in a rural village with few opportunities to improve her income, her ex-husband works in the city and earned substantially more than she does. Kagiso demonstrates an awareness of the unevenness of their financial lives and actively pursues a way of overcoming such inequality.

In another case, Marthe, unaware that her husband was pursuing a divorce in the courts, sought support from a community member. Marthe explained that her husband had not consulted her family and she did not accept the divorce. By rejecting the divorce and the actions of her husband, she retained the right to use 
the marital home, at least until the matter was heard by a traditional leader. Zukiswa, enlisted the support of social workers to try and resolve the issue. Seeking support from social workers was a way of publically shaming the father, publicising her protest, and achieving a better financial solution.

In pursing different strategies of moving out of the customary marriage and seeking equal opportunities, these women are not tolerating sexism in their interpersonal lives and are looking to improve their class position. Many of the women for instance, negotiate the terms of their separation to their husbands, while they seek and find strategic ways of supporting themselves and open up other avenues of security and well-being.

\section{Discussion}

A fundamental dimension of black South African women's work in exiting a marriage, apparent in the narratives shared by the women, is a struggle to maintain a sense of self, community, and financial well-being. Women in this research are required to reconcile contradictory needs concerning their identity. Coping with and surviving within systems of gender oppression is extremely difficult because the pressures for women to be respectful towards their husbands and elders is pervasive. The findings show us that women make varying choices in negotiating the complicated relationship of preparing to leave a marriage, whilst trying to resist, systems of gender and class exploitation. In negotiating the exit out of a customary marriage with husbands, co-wives or husbands families, a range of individuals can draw on and use multiple forms of coercion such as violence, withdrawal of support (financial, housing or childcare), or social exclusion and marginalisation to assert their control and authority. Some women remain powerless in the face of external forces to comply, other women comply with aspects of the power struggle as a way of maintaining their respectability, while other women resist the pressure to remain in a marriage and challenge inequality. Exploring the dialectical nature of black South African women's struggles of gender subordination and economic exploitation demonstrates the need to broaden understanding of African femininities. Paying attention to how the quest for opportunity is mediated by membership in different extended families, across generations in specific class contexts reveals how women are strategising to maximise security for themselves and their children.

The findings and existing literature demonstrate that women are powerful actors in customary marriage which allows them to overcome a range of structures of power. The women who demonstrated ambivalent femininities don't resist the process of transitioning out of a marriage but they do not seek equal 
opportunities as they are concerned about adhering to the cultural milieu and maintaining their respectability in the process. Although women make choices about leaving the marriage, these are constructed within the realms of acceptability and ideological understanding of what a customary wife should endure, and how she should exit the marriage (without any claim to the joint property). These women demonstrate a strong gender consciousness but they do not make a connection between their own deprived financial situation post marriage and that of their husbands. The power displayed is not wholly enabling and when we adopt a more complex, interrelated notion of power (BarakeYusuf, 2004: 71) we find that this power is subject to and operating in the context of other forms of binding power and social control, mostly the power of lineage and social positions. This analysis of women leaving marriages to seek greater autonomy but not fighting for equality of income or opportunity provides one baseline from which women negotiate and it highlights the potentialities of their resistance.

Women who demonstrated alternative femininities are fighting a new area of struggle - the financial arena - and are attempting to renegotiate the social and economic relations between genders and families. In many instances they are openly challenging and overturning the way in which matters get resolved. This is a sign of historical transformation (belief and fight for financial compensation) that has opened up this new area of struggle. They do not see the comparison between their world and their husband's world as legitimate. The disparity is judged unjust as the women believe it results from traditional structures which hold them back. The women believe that husbands and their families have too much influence in the outcome. They have a raised class consciousness as they make a connection and comparison between their own financial post-separated situation and that of their former husbands.

Many of the patterns of compliance identified in this paper highlight the historical imprint of subordination which reinforces gender ideologies in which men and men's families remain dominant in the eyes of customary wives. The process of compliance both reflects, contributes and reproduces women's marginalised and subordinate status in marriage, families and societies. Moreover, in socio-economic environments where dependent wives rely on the support from the wider kin group, choices and actions are often the result of poverty and desperation rather than deference to patriarchal norms. Resonating with Kandiyoti's (1998) findings, those women who were unable to accept the form of oppression but also unable to eliminate the sources of their oppression simply managed it as best as they could. The focus on relational aspects of gender does not isolate gender from racial, class or other disadvantages due to lineage or social positions. 
Gender and class consciousness through a recognition of abuse and infidelity and deprived condition, has forced women to question the legitimacy of cultural practices. Women observe how men and often their families, following the end of the customary marriage, play different roles and have different resources. As Kandiyoti (1998) argued patriarchal bargains are not timeless, but are susceptible to historical transformation that open up new areas of struggle and renegotiations of relations between genders. The findings point towards a shared struggle for the rejection of infidelity and intimate partner violence and the start of a quest for equal opportunities following the breakdown of a customary marriage. Economic disadvantage is no longer acceptable for some women, perhaps given the new era of rights and equality which arrived with the RCMA and constitutional protection. The potent mix of tradition, colonial legacy and cultural belief in the subordination of women remains problematic. However, this paper at least points to a moment of flux and transition. The emerging forms of femininities of women in customary marriages in the face of these strong patriarchal alliances could signal an emerging democratic gender politics at the intersection of class, seniority and social positions. 


\section{References}

Amadiume, I. 1987. Male Daughters, Female Husbands: Gender and Sex in an African Society. London: Zed Books.

Arnfred, S. 2007. Sex, Food and Female Power: Discussion of Data Material from Northern Mozambique. Sexualities, 10(2): 141-158.

Bakare-Yusuf, B. 2004. 'Yoruba Don't Do Gender': A Critical Review of Oyeronke Oyewumi's The Invention of Women: Making An African Sense of Western Gender Discourses African Gender Scholarship: Concepts, Methodologies and Paradigms (pp. 61-82): Council for the Development of Social Science Research in Africa.

Budlender, D.; Mbgweba, S.; Motsepe, K. \& L. Williams. 2011. Women, Land and Customary Law. Johannesburg: Community Agency for Social Enquiry.

Burman, S. 2008. Protecting the Vulnerable from 'Property Grabbing: The Reality of Administering Small Estates. South African Law Journal, 125(1): 134-156.

Burman, S. 1987. Marriage Break-Up in South Africa: Holding Want at Bay? International Journal of Law, Policy and the Family, 2: 206-247.

Chanock, M. 1991. Law, Custom, and Social Order: The Colonial Experience in Malawi and Zambia. Portsmouth: Heinemann.

Classens, A. \& S. Ngubane. 2008. Women, Land and Power: The Impact of the Communal Land Rights Act. In Claassens, A. \& B. Cousins (eds.) Land, Power \& Custom: Controversies Generated by South Africa's Communal Land Rights Act. . Cape Town: UCT Press.

Connell, R. 1987. Gender and Power: Society, the Person and Sexual Politics. Cambridge: Polity Press.

Crenshaw, K. 1989. Demarginalizing the intersection of race and sex: A Black feminist critique of antidiscrimination doctrine, feminist theory and antiracist politics. University of Chicago Legal Forum, 140: 139-167.

Deveaux, M. 2003. Liberal Constitutions and Traditional Cultures: the South African customary law debate. Citizenship Studies, 7(2): 161-180. 
England, P. 2010. The Gender Revolution: Uneven and Stalled. Gender and Society, 24(2): 149-166.

Ferree, M. 2010. Filling the Glass: Gender Perspectives on Families. Journal of Marriage and the Family, 72: 420-439.

Griffiths, A. 1997. In the Shadow of Marriage: Gender and Justice in an African Community. Chicago, University of Chicago Press.

Hill Collins, P. H. 1990. Black Feminist Thought: Knowledge, Consciousness and Empowerment. Boston: Unwin Hyman.

Hosegood, V.; McGrath, N. \& T. Moultrie. 2009. Dispensing with marriage: Marital and partnership trends in rural KwaZulu-Natal, South Africa 2000-2006. Demographic Research, 20(13): 279-312.

Jewkes, R. \& R. Morrell. 2010. Gender and sexuality: emerging perspectives from the heterosexual epidemic in South Africa and implications for HIV risk and prevention. Journal of International AIDS Society, 13(6).

Kandiyoti, D. 1988. Bargaining with Patriarchy. Gender and Society, 2(3): 274290.

Magwaza, T. 2001. Private Transgression: The Visual Voice for Zulu Women. Agenda, 49: 25-32.

Mamashela, M. 2004. New Families, New Property, New Laws: The Practical Effects of the Recognition of Customary Marriages Act. South African Journal on Human Rights, 20(4): 616-41.

Mathonsi, N. \& M. Gumede. 2006. Communicating through performance: Izigiyo azwomame as gendered protest texts. Southern African Linguistics and Applied Language Studies, 24(4): 483-494.

Mbatha, L.; M. Najma \& E. Bonthys. 2007. Culture and Religion. In Bonthys, E \& C. Albertyn (eds.) Gender, Law and Justice. Cape Town: Juta and Company.

Mbatha, T. 2011. In and out of Polygyny: A Case of Black South African Women's Experiences of Marriage. Agenda, 25(1): 29-37. 
McClendon, T. 1995. Tradition and Domestic Struggle in the Courtroom: Customary Law and the Control of Women in Segregation-Era Natal. The International Journal of African Historical Studies, 28(3): 527-561.

Mnisi Weeks, S. 2011. Take Your Rights Then and Sleep Outside, on the Street: Rights, Fora, and the Significance of Rural South African Women's Choices. Wisconsin International Law Journal, 29: 288-318.

Mnisi Weeks, S. 2012. Women's eviction in Msinga: The uncertainties of seeking justice. Acta Juridica, 13: 118-141.

Nhlapo, T. 1991. African Family and Women's Rights: Friends or Foes. Acta Juridica, 13: 135-146.

Oyewùmí, O. 1997. The Invention of Women: Making An African Sense of Western Gender Discourses. London: University of Minnesota Press.

Oyewùmí, O. 2004. Conceptualising Gender: Eurocentric Foundations of Feminist Concepts and the Challenge of African Epistemologies. African Gender Scholarship: Concepts, Methodologies and Paradigms: Council for the Development of Social Science Research in Africa.

Pienaar, J. 2003. African Customary Wives in South Africa: Is There Spousal Equality after the Commencement of the Recognition of Customary Marriages Act? Stellenbosch Law Review, 2: 256-72.

Posel, D. 1995. State, Power and Gender: Conflict over the Registration of African Customary Marriage in South Africa c. 1910-1970. Journal of Historical Sociology, 8(3): 223-56.

Posel, D. \& M. Rogin. 2009. Women, Income and Poverty: Gendered Access to Resources in Post-Apartheid South Africa. Agenda: 23(81): 25-34.

Ramphele, M. 1993. A Bed Called Home: Life in the Migrant Labour Hostels of Cape Town. Cape Town: David Philip.

Rashid, S. F. 2006. Small Powers, Little Choice: Contextualising Reproductive and Sexual Rights in Slums in Bangladesh. IDS Bulletin, 37(5): 69-76.

Samuel, S. 1999. Women married in customary law: no longer permanent minors. Agenda, 15(40): 23-31. 
South African Law Commission. 1998. Harmonisation of the Common Law and Indigenous Law, Report on Customary Marriage. Project 90.

Schmidt, E. 1991. Patriarchy, Capitalism and the Colonial State in Zimbabwe, Signs, 16: 732-757.

Spencer, L.; Ritchie, J. \& W. O'Connor. 2003. Analysis: Practices, principles and processes. In Ritchie, J. \& J. Lewis (eds.) Qualitative research practice: A guide for social science students and research, pp. 200-218. London: Sage.

Walker, C. 1990. Gender and the Development of the Migrant Labour System c1850-1930. In Walker, C. (ed.) Women and Gender in Southern Africa to 1945. Cape Town: David Philip. 